\title{
SISTEM INFORMASI CONTROLLING AND SELLING PADA CENTURY COMPUTER CENTER MENGGUNAKAN METODE SDLC
}

\author{
Ikke Cristiana ${ }^{1}$, Irawan Setiadi ${ }^{2}$ \\ ${ }^{1,2}$ Universitas Indraprasta PGRI \\ Jl. Raya Tengah No. 80, Kel. Gedong, Kec. Pasar Rebo, Jakarta Timur 13760, Jakarta \\ 1 cristianaikke@gmail.com, ${ }^{2}$ irawan.setiadi91@gmail.com
}

\begin{abstract}
ABSTRAK
Century Computer Center beralamat di J1. Mangga Dua Raya No.11, RT.17/RW.11, Ancol, Kec. Pademangan, Kota Jakarta Pusat. Namun pada implementasi controling and selling masih menggunakan sistem yang manual dari mulai pendataan stok barang sampai dengan pembuatan laporan. Tujuan penelitian ini adalah membangun sistem informasi yang terkomputerisasi sehingga proses menjadi efektif dan efisien. Metode yang digunakan penulis yaitu dengan menggunakan pengembangan aplikasi SDLC yaitu waterfall dan metode pengumpulan data yang diterapkan ialah observasi, wawancara dan studi kepustakaan, dan pada tahap pengujian dilakukan dengan cara BlackBox Testing. Cara pengujian dilakukan dengan menjalankan aplikasi Sistem Informasi Controlling And Selling dan melihat hasil output-nya apakah telah sesuai dengan hasil yang diharapkan. Kegiatan pengujian sistem ini untuk memastikan bahwa program atau sistem yang dibuat masih terdapat bug (kesalahan) atau tidak. Dari setiap pengujian tidak menutup kemungkinan masih terdapat bug (kesalahan) dari sistem yang telah diuji, namun pengujian ini setidaknya dapat meminimalisasikan bug yang terdapat di dalam sistem.
\end{abstract}

Kata Kunci: Sistem Informasi, Controlling, Selling, Black Box.

\begin{abstract}
Century Computer Center is located at Jl. Mangga Dua Raya No.11, RT.17/RW.11, Ancol, Kec. Pademangan, Central Jakarta City. However, in the implementation of buying and selling as well as controlling the stock of goods, they still use a manual system from collecting data on stock of goods to making reports. The purpose of this research is to build a computerized information system so that the process becomes effective and efficient. The method used by the author is to use the SDLC application development, namely the waterfall and the data collection method applied is observation, interviews and literature study, and at the testing stage, it is done by means of BlackBox Testing. The test method is carried out by running the Controlling And Selling Information System application and seeing whether the output results are in accordance with the expected results. This system testing activity is to ensure that the program or system created still has bugs (errors) or not. From each test, it is possible that there are still bugs (errors) from the system that has been tested, but this test can at least minimize the bugs contained in the system.
\end{abstract}

Key Word: Systems Information, Controlling, Selling, Black Box.

\section{PENDAHULUAN}

Perkembangan globalisasi yang diiringi oleh kemajuan teknologi informasi mengakibatkan arus informasi yang dulunya sulit diperoleh, kini dapat diperoleh dengan mudah pada saat dibutuhkan. Perkembangan teknologi yang semakin maju membutuhkan kinerja yang relatif cepat dan akurat dalam suatu instansi atau bisnis untuk menghasilkan informasi yang dibutuhkan. Salah satunya adalah penerapan teknologi komputer sebagai alat bantu yang mutlak digunakan sebagai penunjang utama dalam persaingan usaha dan penunjang sumber daya manusia yang baik. Untuk dapat menciptakan dan mengatasi kondisi tersebut maka diperlukan suatu sistem informasi yang dapat melayani segala macam aspek informasi mengenai kapasitas, keterampilan, keahlian, pengalaman dan potensi pegawai secara cepat, tepat dan tepat yang kemudian dapat digunakan untuk menentukan kebijakan atau keputusan dan implementasinya agar dalam pengolahan data dan sistem informasi controling and selling pada toko Century Computer Center bisa berkembang.

Toko Century Computer Center adalah salah satu toko yang bergerak dalam bidang penjualan komputer seperti PC, notebook dan aksesoris komputer yang lebih tepatnya vendor atau pihak kedua. Toko ini memiliki 
beberapa bagian dalam pekerjaan, salah satunya adanya bagian admin yang memiliki tugas untuk menangani pembelian serta penjualan hingga laporan setiap bulannya, permasalahan yang terjadi ialah pengolahan data barang dan laporan pembelian serta laporan penjualan barang masih dilakukan secara manual ditulis didalam buku besar.

Untuk itu sangat diperlukan sistem yang terkomputerisasi untuk memudahkan dalam kegiatan proses penginput an data, transaksi pembelian serta transaksi penjualan dan juga untuk mengetahui stok barang yang masuk dan keluar sehingga menjadi lebih efektif dan efisien (Fatkhudin, 2016). Maka dari itu sistem yang dirancang menggunakan database harus bisa membantu dalam membuat laporan penjualan, pembelian dan persediaan barang (Ali, 2019).

Perancangan merupakan tahapan untuk menyusun suatu pekerjaan dengan menggunakan berbagai macam cara yang bervariasi dan di dalamnya terdapat penjelasan tentang arsitektur serta kelengkapan komponen dan kekurangan yang dimiliki dalam proses pengerjaannya (Soetam, 2011).

Sedangkan sistem informasi adalah sebuah sistem organisasi yang mempertemukan pengolahan transaksi yang mendukung fungsi operasi suatu organisasi, sistem ini mengubah, menimpan, mengolah, mengambil dan memberikan informasi yang diteruskan dengan menggunakan suatu sistem informasi atau sistem lainnya (Anggraeni, 2017).

Dan definisi penjualan ialah suatu proses persetujuan kedua belah pihak mengenai pertukaran jasa atau barang antara pihak pertama dan pihak kedua (Dharmmesta, 2014). Keputusan pembelian konsumen ialah suatu keputusan akhir perorangan dan rumah tangga yang membeli barang dan jasa untuk konsumsi pribadi(Kotler, 2014).

Berdasarkan permasalahan diatas maka toko Century Computer Center perlu membutuhkan suatu perancangan sistem informasi tentang penjualan yang dapat mendukung pengolahan data penjualan komputer secara cepat, akurat dan tepat serta dapat memberikan kemudahan bagi karyawan dalam bekerja. Dengan ini penulis membuat Sistem informasi controling and selling Pada Century Computer Center yang diharapkan dapat menyelesaikan permasalahan yang ada di perusahaan.

Tujuan dari penelitian ini adalah merancang sistem informasi controling and selling yang meliputi pengolahan data barang, user, supplier, pembelian, penjualan dan pengendalian stok barang. Serta merancangan sistem pembuatan laporan pembelian, penjualan dan pengendalian stok barang.

\section{METODE PENELITIAN}

Rancangan kegiatan dimulai pada bulan Maret 2021 dengan cara mengadakan kunjungan langsung ke lapangan guna mencatat hal-hal penting dan sesuai dengan masalah, lalu melakukan wawancara dengan pemilik toko Century Computer Center. Penelitian dilakukan di toko Century Computer Center yang beralamat Jl. Mangga Dua Raya No.11, RT.17/RW.11, Ancol, Kec. Pademangan, Kota Jakarta Pusat dan dilakukan selama 5 bulan pada bulan Maret tahun 2021 sampai dengan bulan Juli tahun 2021.

Metode pengumpulan data yang digunakan yaitu terdiri dari observasi, wawancara dan studi kepustakaan. Wawancara yaitu sebuah pertemuan yang dilakukan oleh dua orang untuk bertukar informasi maupun suatu ide dengan cara tanya jawab, sehingga dapat dikerucutkan menjadi sebuah kesimpulan atau makna dalam topic tertentu (Sugiyono, 2015).

Dalam pengembangan sistem yang terdapat pada Toko Century Computer Center, penulis menggunakan SDLC (Software Development Life Cycle atau sering disebut juga System Development Life Cycle yaitu pengembangan atau mengupgrade sebuah sistem software menggunakan model dan tata cara yang digunakan seseorang untuk mengupgrade sebuah sistem software sebelumnya (A. S., Rosa dan Shalahuddin, 2018).

Bahasa pemrograman yang digunakan adalah java. Java adalah bahasa pemrograman yang biasa dipakai untuk mengembangkan sebuah software, website, artificial intelligence yang bisa berkomunikasi melalui internet ataupun jaringan lainnya(Haryanto, 2011). Netbeans 
merupakan salah satu IDE yang dikembangkan dengan pengembang bahasa pemrograman java, Netbeans mempunyai pemrograman data yang di dalamnya menyediakan pembangunan pemrograman GUI, text editor, compiler, dan interpreter (Westriningsih, 2012).

Sistem informasi menggunakan $M y S Q L$ dalam mengelola database dengan cepat dan menampung jumlah yang sangat besar serta dapat diakses oleh banyak pengguna (Raharjo, 2011). MySQL adalah salah satu dari jenis database server yang sangat terkenal dan banyak digunakan untuk membangun aplikasi web yang menggunakan database sebagai sumber dan pengolahan datanya (Arief, 2011). Dan dengan penggunaan database dalam penyimpanan data memberikan kerapian dan keamanan data. Karena menggunakan database yang sudah disimpan akan mengurangi resiko dari kehilangan data (Fitri et al., 2018).

Aplikasi pengembang yang digunakan adalah XAMPP. XAMPP adalah software open source yang dapat di download secara free dan dapat digunakan di semua sistem operasi seperti windows, linux, solaris, dan mac(Buana, 2014). XAMPP ialah program web yang biasa digunakan untuk memulai pemrograman web, khususnya PHP dan MySQL(Nugroho, 2013).

\section{HASIL DAN PEMBAHASAN}

Berdasarkan hasil penelitian masalah sebelumnya, peneliti memberikan analisa permasalahan dari sistem pengelolaan data diantaranya:

1. Pengolahan setiap transaksi pembelian dan transaksi penjualan masih manual dengan menggunakan buku besar dalam setiap pencatatannya, sehingga sering terjadi kesalahan-kesalahan yang akan menyebabkan kerugian bagi toko Century Computer Center dan pembuatan laporan kepada pemilik toko masih membutuhkan banyak waktu sehingga tidak efisien.

2. Pengecekan data stok barang di perusahaan ini dengan cara mengecek satu persatu data stok barang sehingga pengecekan tidak efisien.

3. Pembuatan laporan pembelian dan laporan penjualan komputer sering sekali terlambat diberikan kepada pemilik toko dikarenakan penyimpanan nya masih manual.

Berdasarkan masalah yang terdapat pada toko Century Computer Center, maka tahap pengujian dilakukan dengan cara BlackBox Testing. Cara pengujian dilakukan dengan menjalankan aplikasi Sistem Informasi Controlling And Selling dan melihat hasil output-nya apakah telah sesuai dengan hasil yang diharapkan, yaitu :

Tabel 1. Hasil Pengujian BlackBox Testing

\begin{tabular}{|c|c|c|c|}
\hline No & $\begin{array}{c}\text { Skenario } \\
\text { Pengujian } \\
\end{array}$ & $\begin{array}{c}\text { Hasil yang } \\
\text { diharapkan }\end{array}$ & Kesimpulan \\
\hline 1 & $\begin{array}{l}\text { Memasukan } \\
\text { username } \\
\text { atau } \\
\text { password } \\
\text { atau } \\
\text { keduanya } \\
\text { yang belum } \\
\text { tersimpan } \\
\text { pada } \\
\text { database } \\
\text { lalu klik } \\
\text { tombol } \\
\text { "Login". }\end{array}$ & $\begin{array}{l}\text { Sistem akan } \\
\text { menolak akses } \\
\text { login dan } \\
\text { menampilkan } \\
\text { pesan } \\
\text { "Username atau } \\
\text { Password } \\
\text { Salah". }\end{array}$ & Berhasil \\
\hline 2 & $\begin{array}{l}\text { Memasukan } \\
\text { username } \\
\text { dan } \\
\text { password } \\
\text { yang sesuai } \\
\text { dalam } \\
\text { database } \\
\text { lalu klik } \\
\text { "Login". }\end{array}$ & $\begin{array}{l}\text { Sistem akan } \\
\text { menampilkan } \\
\text { pesan "Login } \\
\text { Berhasil" dan } \\
\text { menuju halaman } \\
\text { utama. }\end{array}$ & Berhasil \\
\hline 3 & $\begin{array}{l}\text { Memilih } \\
\text { menu } \\
\text { Barang. }\end{array}$ & $\begin{array}{l}\text { Sistem } \\
\text { menampilkan } \\
\text { Halaman } \\
\text { Barang yang } \\
\text { berisikan form } \\
\text { dan tabel data } \\
\text { yang terkoneksi } \\
\text { dengan } \\
\text { database. }\end{array}$ & Berhasil \\
\hline 4 & $\begin{array}{l}\text { Pada } \\
\text { halaman } \\
\text { Barang, lalu } \\
\text { isi form dan } \\
\text { klik } \\
\text { "simpan" }\end{array}$ & $\begin{array}{l}\text { Data Barang } \\
\text { akan bertambah } \\
\text { ke dalam } \\
\text { database dan } \\
\text { tabel pada } \\
\text { halaman } \\
\text { Teknisi. }\end{array}$ & Berhasil \\
\hline 5 & $\begin{array}{l}\text { Pada } \\
\text { halaman } \\
\text { Barang pilih } \\
\text { baris data } \\
\text { pada tabel } \\
\text { dan klik } \\
\text { tombol } \\
\text { "edit", ubah } \\
\text { data lalu klik } \\
\text { "simpan". }\end{array}$ & $\begin{array}{l}\text { Data yang } \\
\text { terpilih dari } \\
\text { tabel akan } \\
\text { termuat pada } \\
\text { form dan data } \\
\text { tersebut akan } \\
\text { ter-update pada } \\
\text { database dan } \\
\text { tabel data }\end{array}$ & Berhasil \\
\hline 6 & $\begin{array}{l}\text { Pada } \\
\text { halaman }\end{array}$ & $\begin{array}{l}\text { Data yang } \\
\text { terpilih dari }\end{array}$ & Berhasil \\
\hline
\end{tabular}




\begin{tabular}{|c|c|}
\hline $\begin{array}{l}\text { Barang pilih } \\
\text { baris data } \\
\text { pada tabel } \\
\text { dan klik } \\
\text { tombol } \\
\text { "hapus", }\end{array}$ & $\begin{array}{l}\text { tabel akan } \\
\text { termuat pada } \\
\text { form dan data } \\
\text { tersebut akan } \\
\text { terhapus pada } \\
\text { database dan } \\
\text { tabel data }\end{array}$ \\
\hline
\end{tabular}

Diagram Konteks Sistem yang Diusulkan Berikut adalah gambaran sistem yang diusulkan untuk toko Century Computer Center :

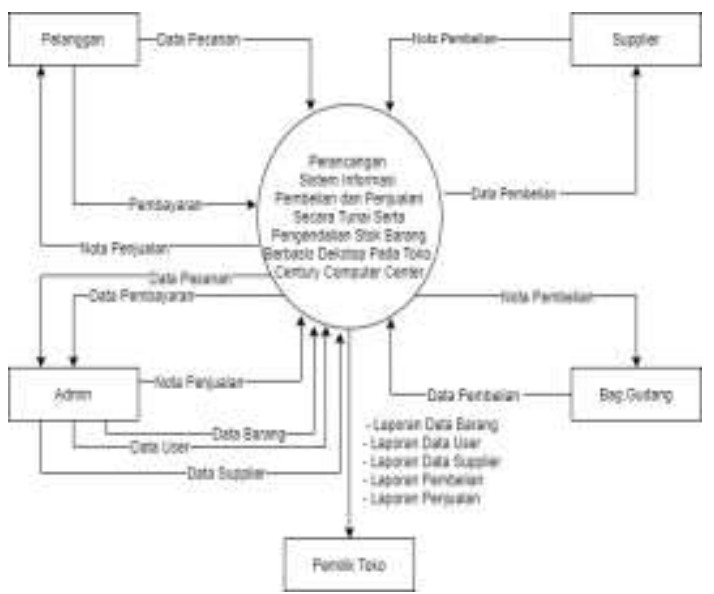

Gambar1. Diagram Konteks Sistem Diagram Nol Sistem

Diagram nol merupakan gambaran proses sistem berjalan pada sistem penjualan yang menggambarkan tahap-tahap proses dari diagram konteks, yaitu:

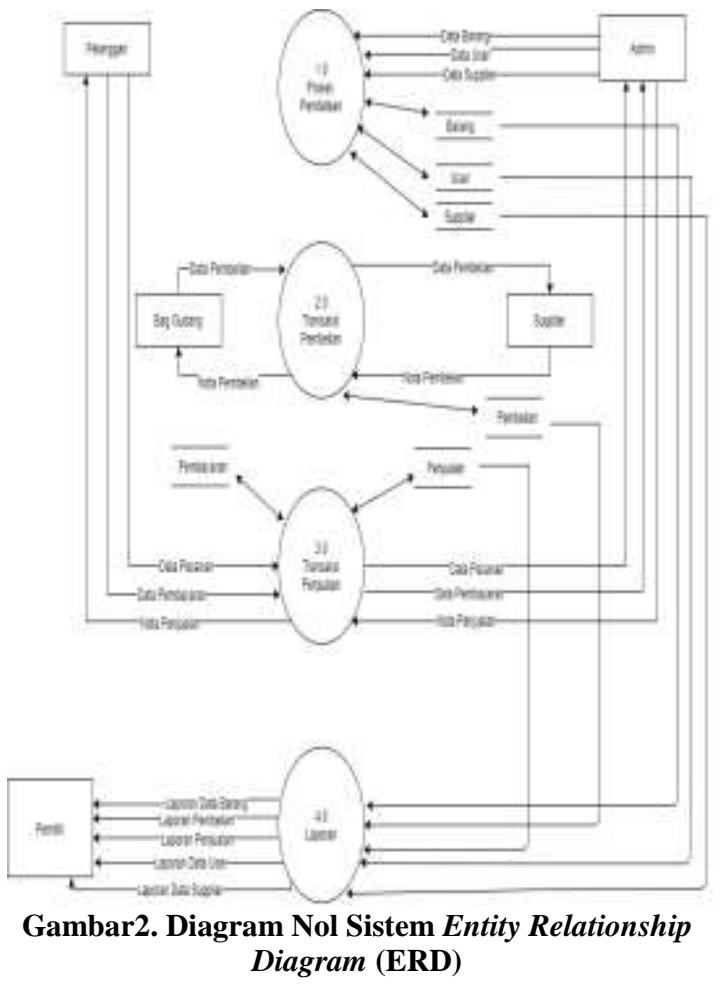

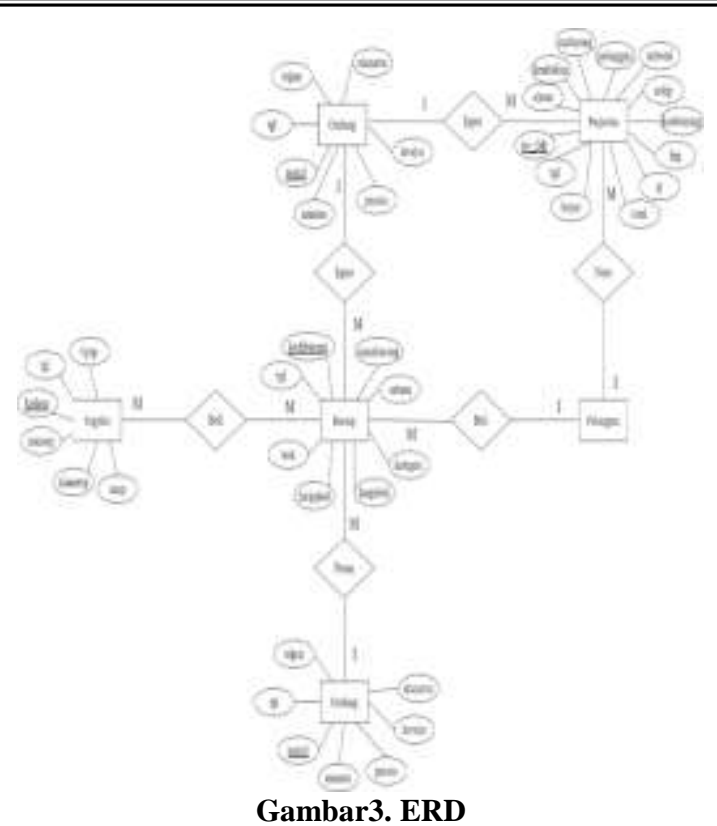

Normalisasi Tahap Pertama (1NF)
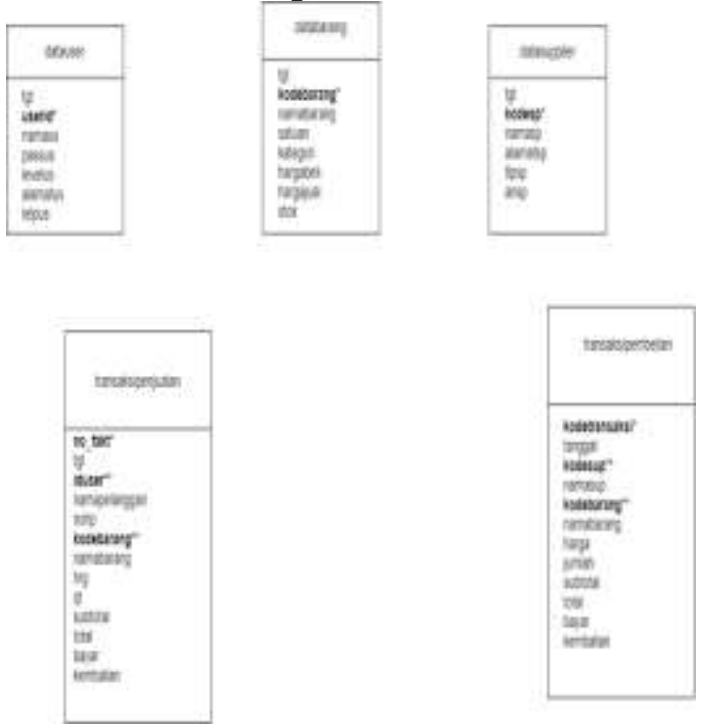

Gambar4. Normalisasi Tahap Pertama (1NF)

\section{Normalisasi Tahap Kedua (2NF)}

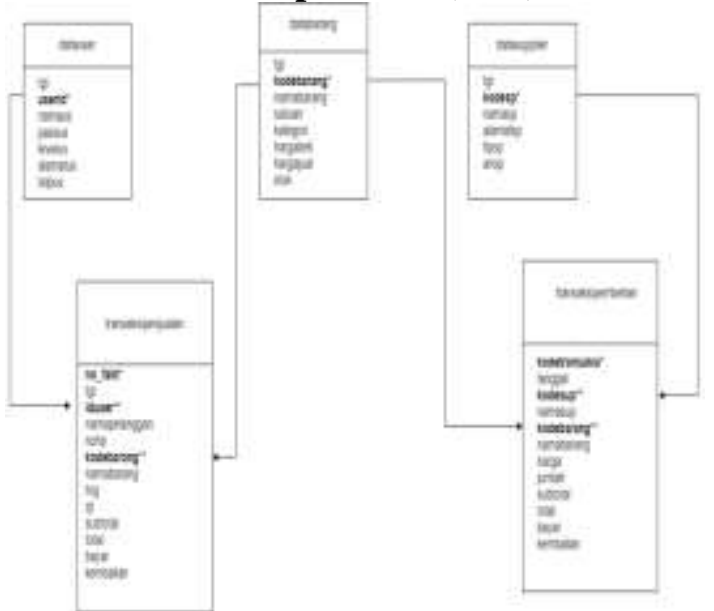

Gambar5. Normalisasi Tahap Kedua (2NF)

23 | Sistem Informasi Controlling and Selling pada Century Computer Center Menggunakan Metode SDLC 


\section{Tampilan Menu Login}

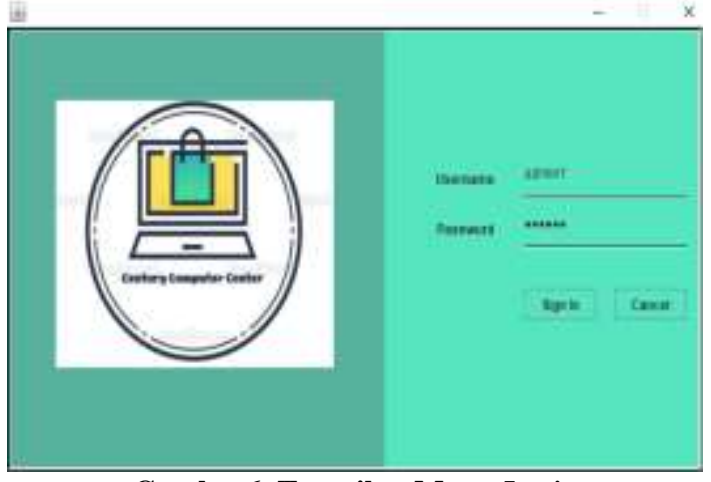

Gambar6. Tampilan Menu Login

Tampilan ini terdapat pada awal program. Menu Login dibuat agar tidak sembarang orang bisa mengakses sebuah program. Maka dari itu kerahasiaannya harus tetap terjaga dengan baik.

\section{Tampilan Menu Home}

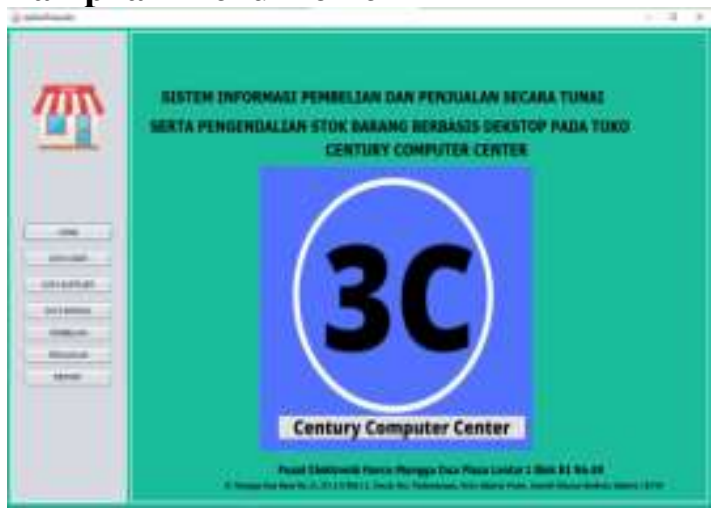

Gambar7. Tampilan Menu Home

Tampilan menu home terdapat beberapa menu yaitu :

a. Data user untuk menampilkan form data user.

b. Data supplier untuk menampilkan form data supplier.

c. Data barang untuk menampilkan form data barang.

d. Data pembelian untuk menampilkan form pembelian.

e. Data penjualan untuk menampilkan form penjualan.

f. Report untuk menampilkan form laporan.
Tampilan Menu Data Barang

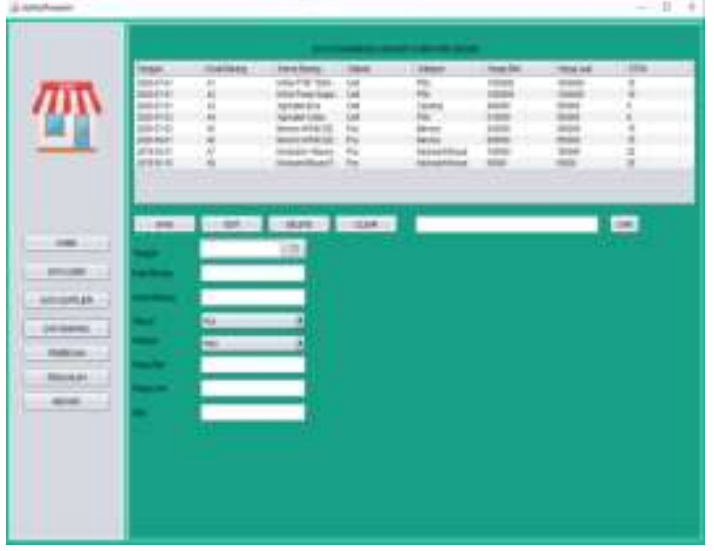

Gambar8. Tampilan Menu Data Barang

Layar di atas menampilkan tampilan form data barang. Pada layar form data barang untuk meng-input data barang yang terdiri dari Tanggal, Kode Barang, Nama Barang, Satuan, Kategori, Harga Beli, Harga Jual dan Stok.

\section{Tampilan Menu Pembelian}

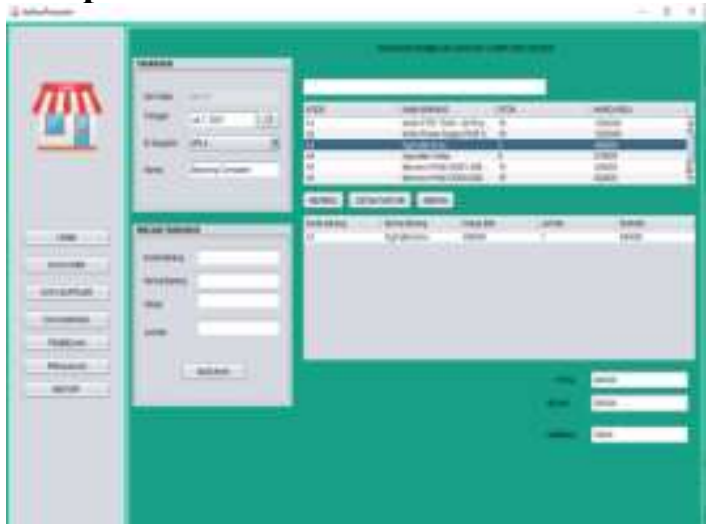

Gambar9.Tampilan Menu Pembelian

Pada layar form data pembelian untuk menginput data pembelian yang terdiri dari No.Faktur, Tanggal, ID Supplier, Nama Supplier, Kode Barang, Nama Barang, Harga, Jumlah.

\section{Tampilan Menu Penjualan}

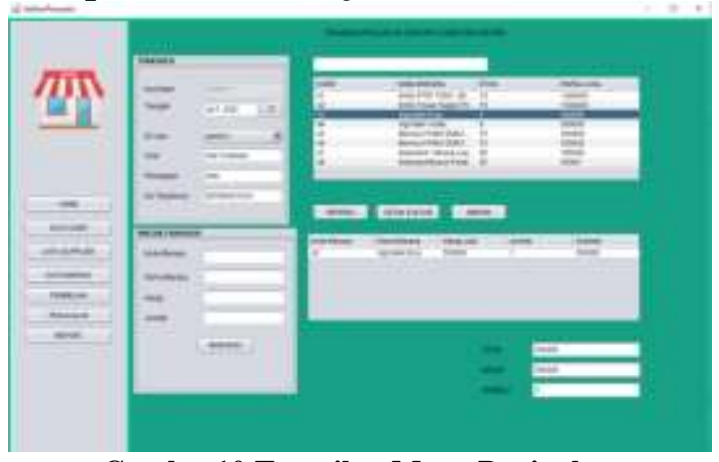

Gambar10.Tampilan Menu Penjualan 
Layar di atas menampilkan tampilan form data penjualan. Pada layar form data penjualan untuk meng-input data penjualan yang terdiri dari No.Faktur, Tanggal, AdminID , Nama Admin, Pelanggan, No.Telepon, Kode Barang, Nama Barang, Harga, Jumlah.

\section{Tampilan Laporan Data Barang}

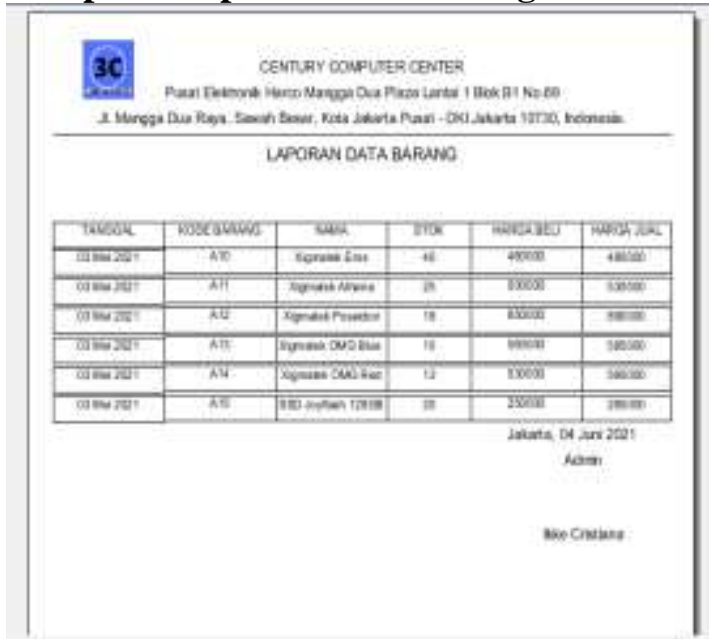

Gambar11.Tampilan Laporan Data Barang

Tampilan laporan Data Barang yaitu menampilkan keseluruhan data barang yang akan digunakan untuk mengecek laporan data barang terdiri Tanggal, Kode Barang, Nama Barang, Stok, Harga Beli dan Harga Jual.

\section{Tampilan Laporan Pembelian}

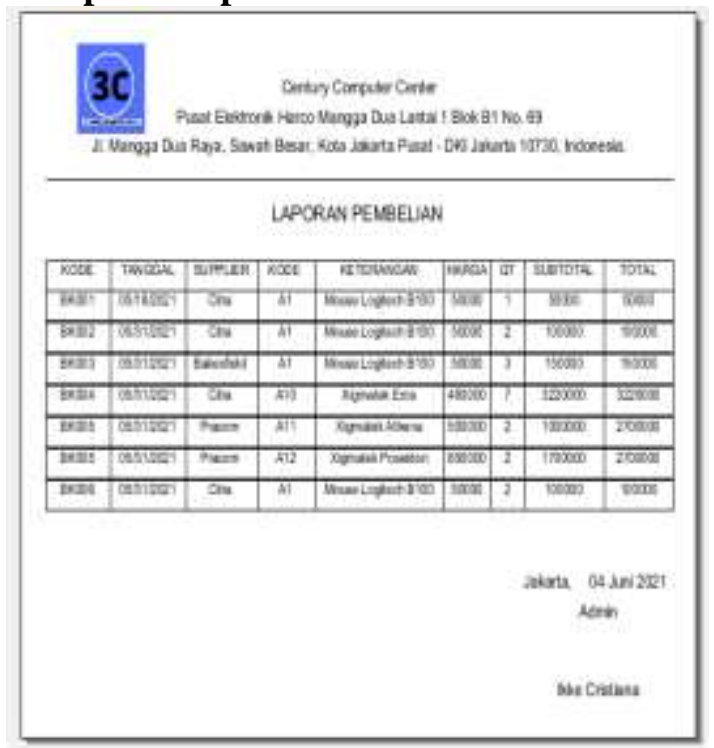

Gambar12.Tampilan Laporan Pembelian

Layar di atas menampilkan tampilan form laporan data pembelian pada layar form data pembelian digunakan untuk mengecek laporan pembelian terdiri Kode Transaksi,
Tanggal, Supplier, Kode Barang, Nama Barang, Harga, Stok, Subtotal dan Total.

\section{Tampilan Laporan Penjualan}

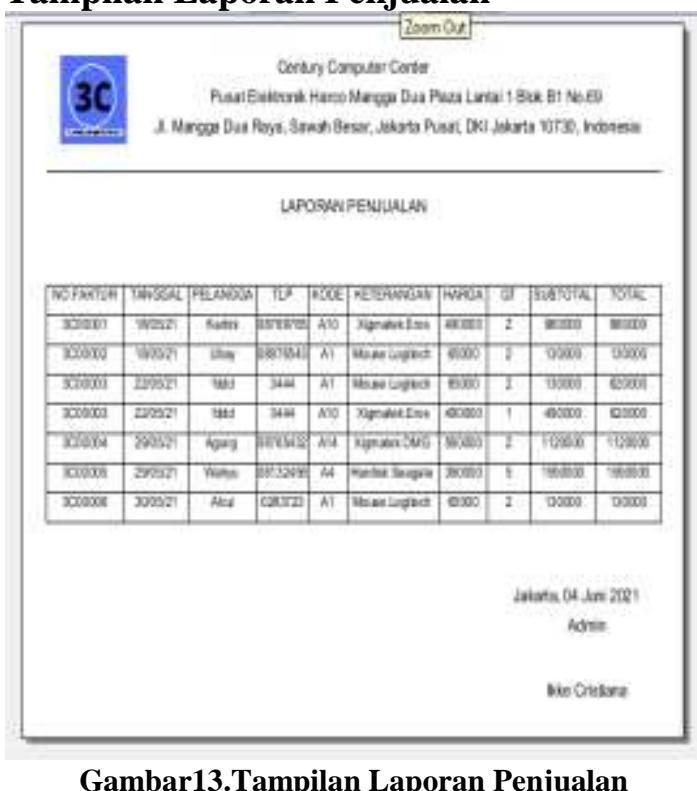

Tampilan laporan Penjualan yaitu menampilkan keseluruhan data penjualan yang digunakan untuk mengecek laporan penjualan terdiri Kode Transaksi, Tanggal, Pelanggan, No.Telepon, Kode Barang, Nama Barang, Harga, Jumlah, Subtotal dan Total.

\section{Tampilan Nota Pembelian}

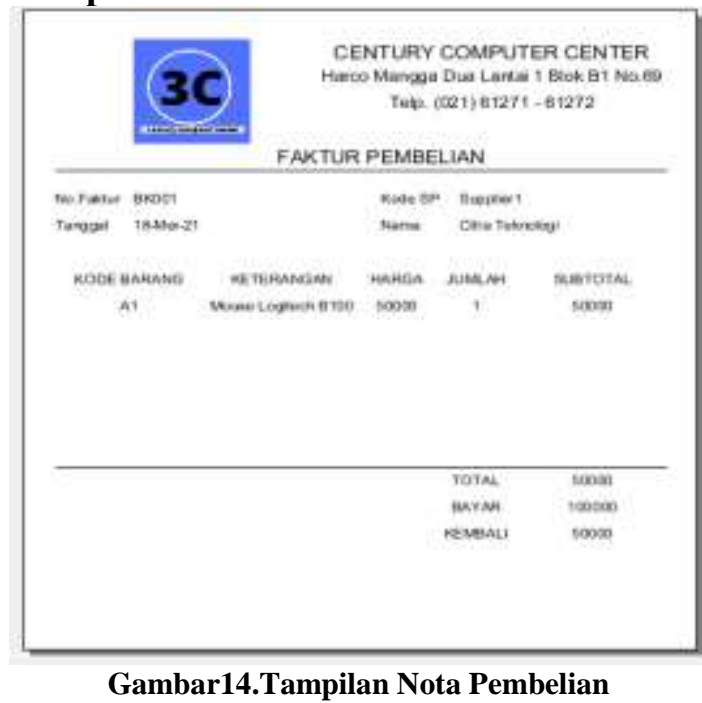

Layar di atas menampilkan tampilan layar nota pembelian digunakan untuk bukti pembelian terdiri Kode Transaksi, Tanggal, Kode Supplier, Nama Supplier, Kode Barang, Nama Barang, Harga, Jumlah, Subtotal, Total dan Kembalian. 
Tampilan Nota Penjualan

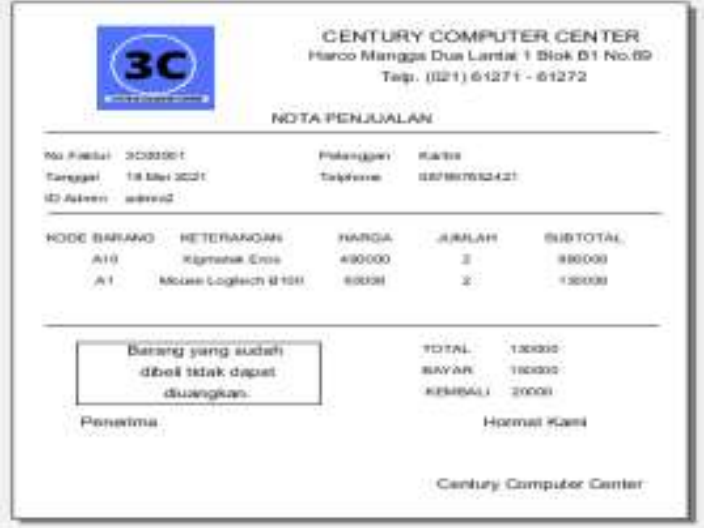

Gambar15.Tampilan Nota Penjualan

Layar di atas menampilkan tampilan layar nota penjualan digunakan untuk bukti penjualan terdiri Kode Transaksi, Tanggal, AdminID, Pelanggan, No.Telepon, Kode Barang, Nama Barang, Harga, Jumlah, Subtotal, Total dan Kembalian.

\section{SIMPULAN DAN SARAN}

Berdasarkan penelitian yang telah dilakukan penulis mengenai perancangan sistem informasi controling and selling pada toko Century Computer Center, dapat diambil kesimpulan bahwa sistem informasi controling and selling pada toko Century Computer Center ini dapat mengelola data penjualan komputer secara cepat, akurat dan tepat serta memudahkan karyawan dalam bekerja. Dengan adanya sistem ini dapat meningkatkan efisien dan efektifitas kinerja dalam proses controling and selling pada toko Century Computer Center. Dengan menggunakan sistem yang sudah terkomputerisasi diharapkan dapat meminimalis adanya kehilangan data dalam proses controling and selling pada toko Century Computer Center.

Berdasarkan hasil evaluasi terhadap sistem informasi yang penulis bangun terdapat beberapa saran untuk pengembangan diantaranya adalah pembuatan sistem informasi pembeliandan penjualan serta pengendalian stok barang ini masih dapat dikembangkan seiring dengan berkembangnya spesifikasi kebutuhan pengguna, terutama dalam hal tampilan ada baiknya dibuat tampilan yang lebih menarik dan dikembangkan lebih lanjut. Masih banyak menu lain yang dapat dikembangkan dalam perangkat lunak ini misalnya return transaksi pembelian dan transaksi penjualan, pengembangan tersebut tentunya dapat meningkatkan mutu sistem yang lebih baik.

\section{DAFTAR PUSTAKA}

A. S., Rosa dan Shalahuddin, M. (2018). Rekayasa Perangkat Lunak Terstruktur dan Berorientasi Objek. Informatika.

Abdullah, T. \& F. T. (2016). Manajemen Pemasaran. PT Raja Grafindo Persada.

Ali, A. F. (2019). Rancang Bangun Aplikasi Penjualan Barang Berbasis Java Programming. Simtika, 2(1), 8-17.

Anggraeni, E. . \& I. (2017). Pengantar Sistem Informasi. Andi.

Arief, M. R. (2011). Pemrograman Web Dinamis Menggunakan PHP dan MYSQL. Andi.

Buana. (2014). Aplikasi XAMPP. Andi.

Dharmmesta, B. S. (2014). Manajemen Pemasaran. BPFE.

Fatkhudin. (2016). Toko Elektronik Lubada Jaya Kajen Dengan. Jurnal Digit, 6(1), 23-36.

Fitri, R. S., Rukun, K., \& Dwiyani, N. (2018). Perancangan Dan Implementasi Sistem Informasi Penjualan Komputer Dan Accessories Pada Toko Mujahidah Computer Berbasis Web. Voteteknika (Vocational Teknik Elektronika Dan Informatika), $4(1)$. https://doi.org/10.24036/voteteknika.v4 i1.6145

Haryanto, B. (2011). Esensi-esensi Bahasa Pemrograman Java. Andi.

Kotler, P. \& K. L. K. (2014). Principle Of Marketing (15th ed.). Pearson Pretice Hall, Inc.

Nugroho. (2013). Mengenal XAMPP Awal. MediaKom.

Raharjo, B. (2011). Belajar otodidak membuat database menggunakan MySQL. Informatika.

Soetam, R. (2011). Konsep Dasar Rekayasa Perangkat Lunak. PT.Prestasi Pustakaraya.

Sugiyono. (2012). Metode Penelitian Kuantitatif Kualitatif dan $R \& B$. Alfabeta.

Sugiyono. (2015). Metode Penelitian Kuantitatif. Kualitatif dan $R \& D$. Alfabeta.

Westriningsih. (2012). Panduan Aplikatif \& Solusi (PAS) Membangun Aplikasi Bisnis dengan Netbeans 7. Andi. 